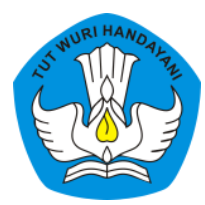

\title{
PEMBELAJARAN IPA BERBASIS MIND MAPPING DALAM PENGEMBANGAN KEMAMPUAN BERPIKIR KRITIS, KREATIF, KOMUNIKATIF, DAN KOLABORATIF
}

\author{
Minarti Taib \\ Sekolah Menengah Pertama Negeri Widyakrama, Gorontalo, Indonesia \\ Contributor Email: minartitaib@gmail.com
}

Received: Feb 15, 2021

Accepted: Apr 16, 2021

Published: Jul 30, 2021

Article Url: https://ojsdikdas.kemdikbud.go.id/index.php/didaktika/article/view/345

\begin{abstract}
Mind mapping based learning is learning to use keyword, terms, images/symbols, describing the integrity of a material. This learning can encourage students to develop thinking technique in all directions, remembering, taking notes, increasing motivation and being able to deduce the results well. The ability of students to think critically and creatively, communicate and collaborate are abilities that must be developed from an early age to enter global competition. This paper aims to describe the science based on mind mapping in developing critical thinking, creative, communicative, and collaborative skills; as well as knowing the development of critical thinking, creative, communicative, and collaborative skills through mind mapping science learning. The form of research is classroom action research carried in 2 cycles using non-test instrument namely observation and interview sheets. The data obtained were processed descriptively using percentage analysis. Based on the results of data analysis, mind mapping based learning can arouse motivation and interest in learning, communicating and collaborating, more constructing knowledge, learning easier. Mind mapping based science learning can develop critical and creative thinking skills respectively by 35\%, communicative 40\%, and collaborative by $35 \%$.
\end{abstract}

Keywords: Learning; Critical; Creative; Communicative; Collaborative 


\begin{abstract}
Abstrak
Pembelajaran berbasis mind mapping merupakan pembelajaran menggunakan peta pikiran melalui kata kunci, istilah, gambar/simbol, menggambarkan keutuhan materi. Pembelajaran tersebut dapat mendorong peserta didik dalam mengembangkan teknik berpikir ke segala arah, mengingat, membuat catatan, meningkatkan motivasi serta dapat menyimpulkan hasilnya dengan baik. Kemampuan peserta didik dalam berpikir kritis dan kreatif, berkomunikasi serta berkolaborasi adalah kemampuan yang harus dikembangkan sejak dini untuk memasuki persaingan global. Penelitian ini bertujuan mendeskripsikan pembelajaran IPA berbasis mind mapping yang digunakan dalam pengembangan kemampuan peserta didik berpikir kritis, kreatif, komunikatif, dan kolaboratif; serta mengetahui perkembangan kemampuan berpikir kritis, kreatif, komunikatif, dan kolaboratif melalui pembelajaran IPA berbasis mind mapping. Bentuk penelitiannya adalah penelitian tindakan kelas dilaksanakan dalam 2 siklus menggunakan instrumen nontes yakni lembar observasi dan wawancara. Data yang diperoleh diolah secara deskriptif menggunakan analisis prosentase. Berdasarkan hasil analisis data, pembelajaran IPA berbasis mind mapping dapat membangkitkan motivasi dan minat belajar, berkomunikasi dan berkolaborasi, lebih kritis dan kreatif dalam mengonstruksi pengetahuan dan belajar lebih mudah. Pembelajaran IPA berbasis mind mapping dapat mengembangkan kemampuan berpikir kritis dan kreatif masing-masing sebesar 35\%, komunikatif 40\%, dan kolaboratif sebesar 35\%
\end{abstract}

Kata Kunci: Pembelajaran; Kritis; Kreatif; Komunikatif: Kolaboratif

\title{
A. Pendahuluan
}

Kemampuan profesionalisme seorang guru sebagai pendidik dalam menjalankan tanggung jawabnya menjadi fasilitator, motivator, dan mediator amatlah penting dalam menentukan kualitas pendidikan. Tetapi hal itu tidak bisa dicapai bila tidak disertai dengan upaya guru untuk meng-upgrade dirinya. Selain itu, mengembangkan sistem pembelajaran dapat memupuk sikap percaya diri guru dalam berinovasi dan berkreasi. Keberhasilan dalam kegiatan pembelajaran pada satuan pendidikan sangat menentukan kualitas pendidikan di tempat tersebut. Oleh sebab itu, sebaiknya guru bersikap proaktif melakukan pembaharuan di bidang pendidikan, bertanggung jawab dan berperan aktif dalam menciptakan karya-karya inovatif dan kreatif untuk mengembangkan kompetensi dalam mengelola aktivitas pembelajaran menarik dan menyenangkan. 
Dalam melaksanakan tanggung jawab dan profesi mengajar, guru dituntut dapat mengimplementasikan berbagai pendekatan, strategi, model, dan metode yang dilandasi pada prinsip efektivitas dan efisiensi serta keterlibatan aktif peserta didik dalam mengonstruksi pengetahuan yang diterimanya sehingga bisa meraih keberhasilan yang diharapkan. Berdasarkan Permendiknas No 16 Tahun 2007 tentang standar kualifikasi akademik dan kompetensi guru, di antaranya terdapat salah satu kompetensi inti pedagogik guru yakni guru harus menguasai teori dan prinsip-prinsip dalam pembelajaran yang mendidik. Dalam kompetensi inti tersebut mengharuskan seorang guru dapat menerapkan berbagai teknik, model, pendekatan, metode, dan strategi pembelajaran yang mendidik secara kreatif dalam mata pelajaran diampu (Devi, 2016).

Guru sebagai pelaku otonomi kelas memiliki wewenang untuk melakukan reformasi kelas dalam rangka merubah mindset dan perilaku peserta didik secara perlahan dan berkelanjutan sesuai dengan kebutuhan, perkembangan, dan tuntutan kurikulum. Program Kurikulum 2013 dan tuntutan pembelajaran abad ke-21, diharapkan semua guru bisa menerapkan berbagai strategi atau pendekatan yang bisa menginspirasi dan memotivasi peserta didik untuk berpikir kritis, analitis, dan kreatif dalam mengamati, mengidentifikasi, mengklasifikasi, memahami permasalahan, berkolaborasi dalam memecahkan masalah, serta mengomunikasikan hasil pemecahan masalah tersebut secara lisan atau dalam bentuk laporan. Dalam proses pembelajaran sebaiknya guru selalu melatih kemampuan peserta didik dalam mengamati dan menemukan fakta atau bukti pada suatu fenomena agar dapat memperoleh kebenaran ilmiah. Proses pembelajaran IPA menekankan pada proses berbuat dan mencari tahu melalui pengalaman langsung, dapat menjelajahi dan memahami alam sekitar untuk mengembangkan kompetensi dan pemahaman yang lebih dalam.

Mengingat perkembangan sikap, mental, dan fisik anak pada jenjang SMP sebagian besar berada pada masa transisi dari fase konkret 
ke fase operasi formal, maka sebaiknya mereka mulai dilatih bisa berpikir abstrak. Berdasarkan pengalaman peserta didik kelas VII masih terlalu sulit beradaptasi dengan aturan yang berlaku di SMP Negeri Widyakrama. Hal ini disebabkan peserta didik berada pada masa peralihan dari anak-anak ke masa remaja, sehingga perilaku dan cara berpikirpun sangat berpengaruh pada proses tersebut. Umumnya mereka masih memperlihatkan sikap atau perilaku dan kebiasaan yang belum sesuai harapan terutama dalam proses pembelajaran seperti lebih banyak diam dari pada berbuat, masih mengharapkan bantuan orang lain dari pada berusaha sendiri mencari tahu serta integritas sangat rendah. Untuk mengatasi permasalahan tersebut, upaya yang ditempuh dalam memperbaiki kualitas pembelajaran dan mengembangkan kemampuan peserta didik dalam berpikir kritis, kreatif, komunikatif, dan kolaboratif adalah merancang pembelajaran IPA berbasis mind mapping. Pembelajaran ini bertujuan menciptakan proses pembelajaran lebih efektif, berkualitas, dan bermakna sehingga peserta didik bisa mencapai kompetensi sesuai harapan. Pembelajaran berbasis mind mapping memiliki keungggulan seperti menjadikan peserta didik aktif, kritis, kreatif, dan mandiri serta memahami materi lebih mudah dan utuh. Semakin sering peserta didik membuat mind mapping maka mereka semakin kreatif (Deporter \& Hernacki, 2011).

Permasalahan dalam penelitian ini adalah peserta didik (1) dalam proses pembelajaran sebagian besar kurang konsentrasi dan memiliki integritas sangat rendah, (2) lebih banyak diam dari pada berbuat; (3) selalu mengharapkan bantuan orang lain dari pada berusaha sendiri mencari tahu, (4) cenderung memberikan pendapat kurang logis dan hanya berdasarkan hapalan atau hayalan, dan (5) hanya mampu menjawab soal-soal LOTS (Lower Order Thinking Skills) pada pelaksanaan penilaian harian.

Fokus permasalahan dalam penelitian ini adalah (1) bagaimanakah pembelajaran IPA berbasis mind mapping yang digunakan dalam mengembangkan kemampuan berpikir kritis, kreatif, komunikatif, dan 
kolaboratif? (2) apakah pembelajaran IPA berbasis mind mapping dapat mengembangkan kemampuan berpikir kritis, kreatif, komunikatif, dan kolaboratif? Penelitian ini bertujuan untuk mendeskripsikan (1) pembelajaran IPA berbasis mind mapping yang digunakan dalam mengembangkan kemampuan berpikir kritis, kreatif, komunikatif, dan kolaboratif; (2) perkembangan berpikir kritis, kreatif, komunikatif, dan kolaboratif peserta didik melalui pembelajaran IPA berbasis mind mapping.

\section{B. Metode}

Jenis penelitian ini termasuk penelitian tindakan kelas menggunakan pendekatan kuantitatif dan kualitatitf. Penelitian dilaksanakan melalui 2 siklus, tahapan setiap siklus adalah sebagai berikut.

\section{Perencanaan Tindakan (Planning)}

Peneliti melakukan beberapa persiapan yakni merancang sistem pembelajaran diawali dengan melakukan analisis tentang kemampuan yang sudah atau belum dimiliki oleh peserta didik dan kebutuhan, menetapkan pengalaman belajar yang perlu dimiliki peserta didik, melakukan kajian materi merujuk pada kata kerja operasional kompentensi dasar, merevisi perangkat pembelajaran seperti silabus, rencana pelaksanaan pembelajaran, lembar kerja peserta didik dan bahan ajar disesuaikan dengan strategi dan media yang digunakan, menyusun instrumen, merancang mind mapping yang akan dikirim ke smartphone peserta didik melalui aplikasi telegram, dan menetapkan waktu pelaksanaan disesuaikan dengan jadwal proses pembelajaran.

\section{Pelaksanaan Tindakan (Action)}

Mengimplementasikan tindakan dengan melaksanakan pembelajaran berbasis mind mapping menggunakan media smartphone dengan sistem android dan langkah-langkahnya menggunakan model discovery learning. 


\section{Observasi/Evaluasi (Observation/Evaluation)}

Kegiatan observasi dan evaluasi dilaksanakan secara bersamaan untuk mengamati proses pembelajaran menggunakan instrumen yang telah disiapkan.

\section{Analisis dan Refleksi (Analysis and Reflecting)}

Dilakukan pada setiap akhir siklus yang hasilnya akan menjadi bahan pertimbangan yang harus ditindaklanjuti pada tahap berikutnya.

Subjek penelitian adalah peserta didik Kelas VII-1 berjumlah 20 orang, Penelitian dilaksanakan di SMP Negeri Widyakrama Jl. Achmad A. Wahab Pentadio Timur Telaga Biru Kabupaten Gorontalo, Provinsi Gorontalo.

Pengumpulan data dilakukan menggunakan instrumen non tes yakni lembar observasi untuk mengamati aktivitas guru dan peserta didik selama proses pembelajaran. Fokus pengamatan pada aktivitas guru adalah penerapan langkah-langkah model discovery learning. Aktivitas peserta didik adalah pada saat diskusi kelompok dan presentasi. Untuk melengkapi data penelitian dilakukan wawancara dan hasilnya menjadi data penunjang serta bahan refleksi untuk mengungkap respons peserta didik tentang kepuasan dan ketertarikan terhadap pelaksanaan pembelajaran. Indikator dan subindikator penelitian adalah sebagai berikut.

Tabel 1 Indikator dan Subindikator Berpikir Kritis, Kreatif, Komunikatif, Kolaboratif, dan Produk Mind Mapping

\begin{tabular}{|c|c|c|}
\hline No & Indikator & Subindikator \\
\hline 1 & Berpikir kritis & $\begin{array}{l}\text { Mengidentifikasi masalah, menganalisis informasi, } \\
\text { membuat kesimpulan }\end{array}$ \\
\hline 2 & Kreatif & $\begin{array}{l}\text { Mengajukan/menjawab pertanyaan, mengelaborasi } \\
\text { pengetahuan, memberikan ide yang logis }\end{array}$ \\
\hline 3 & Komunikatif & $\begin{array}{l}\text { Penguasaan konsep/istilah, performance, penggunaan } \\
\text { bahasa }\end{array}$ \\
\hline 4 & Kolaboratif & $\begin{array}{l}\text { Keterlibatan mengerjakan tugas, membantu teman } \\
\text { dalam kelompok, berbagi pengetahuan }\end{array}$ \\
\hline 5 & $\begin{array}{l}\text { Produk mind } \\
\text { mapping }\end{array}$ & $\begin{array}{l}\text { Penggunaan kata kunci/istilah, kesesuaian keterangan } \\
\text { dengan subtopik, penulisan, kerapian, keterbacaan }\end{array}$ \\
\hline
\end{tabular}


Data penelitian diolah secara deskriptif menggunakan analisis prosentase. Nilai kemampuan berpikir kritis, kreatif, komunikatif, dan kolaboratif diambil dari hasil pengamatan proses pembelajaran dan produk tugas mind mapping yang diselesaikan peserta didik secara kelompok. Penetapan kriteria keberhasilan didasarkan pada Penilaian Acuan Patokan (PAP) yang diadaptasi dari Purwanto (2010) yakni.

Tabel 2 Penilaian Acuan Patokan (PAP)

\begin{tabular}{cc}
\hline Nilai & Kriteria \\
\hline $85-100$ & Sangat baik \\
\hline $75-84$ & Baik \\
\hline $65-74$ & Cukup \\
\hline $0-64$ & Kurang \\
\hline
\end{tabular}

\section{Hasil dan Pembahasan}

Penelitian ini dilakukan dalam 2 siklus, pada siklus I membahas materi pencemaran lingkungan (air, udara, dan tanah), sedangkan siklus II membahas materi lanjutan yakni pemanasan global. Pertemuan 1 siklus I, peserta didik melakukan penyelidikan tentang pengaruh deterjen terhadap pergerakan ikan di air, pertemuan ke-2 menganalisis penyebab dan dampak pencemaran udara dan tanah. Siklus II pertemuan ke-1 dan 2, peserta didik menganalisis penyebab dan dampak pemanasan global serta memberikan pendapat/saran tentang upaya menanggulangi pemanasan global. Di akhir setiap pertemuan peserta didik melengkapi mind mapping menggunakan media smartphone berdasarkan hasil pembelajaran yang diikuti. Pada pertemuan ke-3 seluruh kelompok diberi kesempatan melengkapi atau mengoreksi hasil pekerjaan mereka dan dilanjutkan dengan presentasi. Langkah-langkah kegiatan pembelajaran setiap pertemuan siklus I dan II pada dasarnya sama yakni kegiatan pendahuluan, inti, dan penutup. 


\section{Hasil}

Pembelajaran IPA berbasis mind mapping diikuti oleh peserta didik Kelas VII-1 berjumlah 20 orang terdiri dari 10 orang perempuan dan 10 orang laki-laki, dibagi menjadi 4 kelompok heterogen, dan setiap kelompok memiliki anggota 5 orang. Data hasil pembelajaran tersebut dapat dilihat pada tabel berikut.

Tabel 3 Data Hasil Pembelajaran IPA Berbasis Mind Mapping

\begin{tabular}{|c|c|c|c|c|c|c|}
\hline \multirow[b]{2}{*}{ No } & \multirow[b]{2}{*}{ Indikator } & \multicolumn{2}{|c|}{ Siklus I } & \multicolumn{2}{|c|}{ Siklus II } & \multirow[b]{2}{*}{$\begin{array}{c}\text { Perkembangan } \\
\%\end{array}$} \\
\hline & & $\begin{array}{l}\text { Jumlah } \\
\text { Peserta } \\
\text { Didik }\end{array}$ & $\%$ & $\begin{array}{l}\text { Jumlah } \\
\text { Peserta } \\
\text { Didik }\end{array}$ & $\%$ & \\
\hline 1 & Berpikir kritis & 4 & 20 & 11 & 55 & 35 \\
\hline 2 & Kreatif & 4 & 20 & 11 & 55 & 35 \\
\hline 3 & Komunikatif & 5 & 25 & 13 & 65 & 40 \\
\hline 4 & Kolaboratif & 5 & 25 & 12 & 60 & 35 \\
\hline 5 & $\begin{array}{l}\text { Produk Mind } \\
\text { Mapping }\end{array}$ & 5 & 25 & 15 & 75 & 50 \\
\hline
\end{tabular}

Berdasarkan hasil analisis data seperti yang terdapat pada Tabel 3, capaian hasil pembelajaran pada siklus I masih sangat rendah dan belum sesuai harapan. Hasil perolehan aktivitas guru hanya 50\% terlaksana sehingga berdampak pada aktivitas dan kemampuan peserta didik. Pada siklus ini, peserta didik yang memperoleh kriteria sangat baik dan baik pada kemampuan berpikir kritis dan kreatif masing-masing hanya 4 orang atau $20 \%$. Penyebabnya adalah sebagian besar peserta didik kurang konsentrasi atau perhatian pada kegiatan pembelajaran sehingga belum mampu mengidentifikasi masalah, menganalisis informasi, membuat kesimpulan, mengelaborasi pengetahuan dan masih memberikan ide yang kurang logis. Pada aspek kemampuan dalam melakukan komunikasi dan kolaborasi, yang memperoleh kriteria sangat baik dan baik masing-masing hanya 5 orang atau 25\%. Pada aspek ini sebagian 
peserta didik belum menguasai konsep/istilah; penggunaan bahasa, performance, keterlibatan dalam mengerjakan tugas, dan berbagi pengetahuan masih sangat kurang. Sedangkan produk mind mapping hanya 1 kelompok (5 orang atau 25\%) yang bisa melengkapi mind mapping dengan baik dan benar, kelompok lainnya belum mampu menganalisis gambar/simbol, keterkaitan antara keterangan dengan subtopik serta penulisan kata kunci/istilah terutama rumus kimia masih keliru karena kurangnya keterlibatan mereka dalam proses pembelajaran. Rerata perolehan hasil pembelajaran pada siklus I hanya $23 \%$.

Hasil pembelajaran yang diperoleh pada siklus II menunjukkan adanya perkembangan yang signifikan. Aktivitas guru sudah 100\% terlaksana; peserta didik yang memperoleh kriteria sangat baik dan baik pada aspek kemampuan berpikir kritis dan kreatif dalam proses pembelajaran masing-masing 11 orang atau 55\%, bisa berkomunikasi dengan sangat baik dan baik 13 orang atau 65\%, dan berkolaborasi 12 orang atau $60 \%$. Untuk kreativitas pada produk mind mapping memperoleh kriteria sangat baik dan baik adalah 15 orang atau 75\% (3 kelompok). Rerata perolehan pada siklus ini adalah $62 \%$.
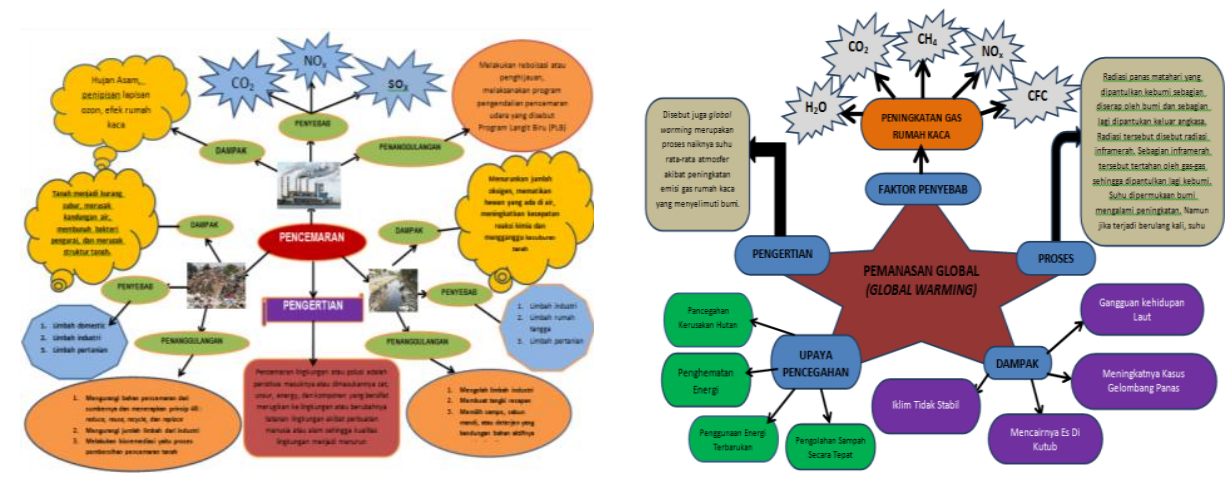

Gambar 1 Mind Mapping Karya Peserta Didik

\section{Pembahasan}

Tidak sedikit guru yang kurang memiliki kemauan dalam mengembangkan kemampuannya dalam berpikir kritis dan kreatif, 
berkolaborasi dengan teman sejawat serta mengomunikasikan hasil karyanya, apalagi memfasilitasi dan memediasi peserta didik mengembangkan kemampuan tersebut dalam pembelajaran. Guru sering mengambil jalan pintas dan langsung memberi tahu kata kunci atau kesimpulan suatu permasalahan, tidak memberi kesempatan seluas-luasnya kepada peserta didik untuk mencari tahu sendiri melalui proses berbuat dan berpikir terutama peserta didik yang memiliki kompetensi rendah.

Program Kurikulum 2013 menuntut guru tidak asal mengajar berdasarkan bahan yang ada, akan tetapi bisa menerapkan model-model pembelajaran yang dapat merubah mindset dan perilaku peserta didik menjadi anak yang memiliki karakter (religiositas, nasionalisme, mandiri, gotong royong, dan intergritas); kemampuan literasi dalam mengembangkan kompetensi pengetahuan dan keterampilan; serta menguasai teknologi.

Materi pembelajaran tentang pencemaran lingkungan dan pemanasan global termasuk materi yang sudah menjadi isue hangat di tingkat nasional dan bahkan internasional karena dampaknya sangat berpengaruh terhadap kehidupan semua makhluk hidup yang ada di bumi. Materi tersebut dirasakan sangat sulit oleh peserta didik karena bersifat kompleks (gabungan dari materi Biologi, Fisika, Kimia) dan abstrak, sehingga guru sangat perlu merancang pembelajaran berbasis mind mapping yang dapat mengembangkan kemampuan mereka dalam berpikir kritis dan kreatif, berkomunikasi, berkolaborasi dalam memecahkan masalah serta mengambil keputusan dengan baik sehingga mereka dapat memahami materi dengan mudah dan cepat.

Langkah-langkah kegiatan pembelajaran yang dilakukan dalam penelitian ini adalah model discovery learning atau belajar penemuan. Fokus dari aktivitas pembelajaran tersebut menitikberatkan pada cara berpikir kritis dan analitis untuk menelusuri dan mendapatkan sendiri solusi dari suatu permasalahan yang diberikan. Pembelajaran ini fokus pada aktivitas peserta didik secara maksimal untuk melakukan berbagai 
kegiatan dalam mengamati, mengidentifikasi masalah, menghimpun informasi, menganalisis, membandingkan, mengintegrasikan, mengategorikan, mereorganisasikan bahan serta membuat kesimpulan untuk memperoleh sendiri suatu konsep. Pengetahuan, pengalaman, dan keterampilan yang diperoleh dalam pembelajaran seperti ini mampu bertahan lama dalam ingatan, memberikan kemudahan untuk memahami materi pembelajaran dengan baik sehingga memungkinkan peserta didik dapat mencapai hasil belajar yang maksimal.

Perolehan hasil pembelajaran IPA berbasis mind mapping pada siklus I belum sesuai harapan. Hal ini diakibatkan aktivitas guru dalam menerapkan model discovery learning belum terlaksana secara maksimal. Pada kegiatan awal pembelajaran guru mengondisikan kegiatan, menggali pengetahuan melalui pertanyaan atau fenomena, dan menyampaikan teknik penilaian. Pada kegiatan inti, guru belum memberikan stimulus dan motivasi dengan maksimal sebelum dan selama melakukan penyelidikan, menganalisis, dan mendiskusikan hasil penyelidikan, memberi kesempatan kepada peserta didik yang belum berpartisipasi untuk terlibat aktif dalam kegiatan kelompok. Pada kegiatan akhir pembelajaran guru belum melakukan refleksi terhadap aktivitas yang dilakukan guru dan peserta didik, serta memberikan penghargaan kepada peserta didik yang berkinerja baik. Beberapa aktivitas tersebut belum terlaksana dengan maksimal disebabkan pemanfaatan waktu yang kurang terkontrol dengan baik sehingga aktivitas peserta didik juga belum sesuai harapan. Pada siklus ini, sebagian besar peserta didik belum berpartisipasi aktif dalam melaksankan percobaan atau penyelidikan pada pencemaran air, mendiskusikan dan mempresentasikan hasilnya, kurangnya kemauan untuk mencari tahu, lebih banyak diam dan hanya menunggu hasil pekerjaan dan pemikiran orang lain, masih memberikan pertanyaan yang kurang logis dan tidak sesuai dengan materi diskusi. Beberapa peserta didik menyampaikan pendapat dengan bahasa yang kurang jelas pada 
saat diskusi dan presentasi. Bahkan, masih ditemukan sebagian dari mereka hanya menyontek hasil pemikiran kelompok lain yang belum tentu benar. Mereka masih memiliki karakter integritas (kejujuran dan tanggung jawab) sangat rendah. Hasil wawancara yang dilakukan, sebagian besar peserta didik menunjukkan bahwa belum berani mengajukan/menjawab pertanyaan, mengemukakan gagasan/ide sendiri dengan alasan belum terbiasa, merasa gemetar karena takut dan malu apabila gagasan/pendapat mereka dinyatakan kurang tepat/keliru dan harus diperbaiki.

Beberapa upaya yang dilakukan untuk memperbaiki kelemahan dan kekurangan seperti yang dikemukakan di atas guru melakukan beberapa hal pada pelaksanaan siklus II yakni sebagai berikut.

a. Untuk memperoleh hasil pembelajaran yang maksimal, guru perlu melaksanakan setiap tahapan pembelajaran discovery secara optimal dan memotivasi, memediasi serta memfasilitasi peserta didik melalui bimbingan atau arahan dalam melakukan setiap kegiatan berdasarkan petunjuk pada lembar kerja. Maksimal atau tidaknya peserta didik mengikuti aktivitas pembelajaran tergantung pada kegiatan guru dalam mengatur, mengorganisasi, atau mengondisikan lingkungan belajar. Guru sangat perlu mengimplementasikan proses pembelajaran berbasis aktivitas untuk memberikan ruang atau kesempatan kepada peserta didik dapat memperoleh sendiri konsep pengetahuan. Proses pembelajaran tersebut akan mendorong mereka untuk mengembangkan kreativitas dan kemampuannya dalam berpikir tingkat tinggi (Kemdikbud, 2019).

b. Berusaha menciptakan situasi belajar kondusif yang dapat membangkitkan motivasi dan minat belajar peserta didik sehingga mereka akan berpartisipasi aktif dalam kegiatan pembelajaran melalui cerita yang berkaitan dengan fenomena atau materi yang dibahas dan melakukan ice breaking di awal 
kegiatan pembelajaran. Hal tersebut dilakukan dengan tujuan agar setiap peserta didik berkonsentrasi penuh pada proses pembelajaran, merasa rileks, dan bisa melupakan semua masalah yang terjadi sebelumnya di luar kelas. Sebab kemampuan peserta didik dalam menyerap pengetahuan, pengalaman, dan keterampilan sangat dipengaruhi oleh suasana hati. Mereka akan memperoleh kompetensi tersebut dengan sebaik-baiknya apabila bisa terlibat langsung secara aktif pada proses pembelajaran. Cara guru menciptakan situasi belajar sangat berpengaruh terhadap respons peserta didik dalam pembelajaran. Hal ini sesuai dengan pendapat Slameto (2010) bahwa penerimaan materi pembelajaran jika dilakukan dengan aktivitas peserta didik sendiri baik dalam berpikir maupun berbuat akan memberi kesan yang mendalam dan bertahan lama dalam ingatannya. Kesan tersebut tidak akan hilang begitu saja tetapi diolah, dipikirkan, dan dikeluarkan lagi dalam bentuk yang berbeda, atau mereka memberikan pendapatnya dan menanya sehingga akan menimbulkan situasi diskusi, berbagi pengetahuan, saling memberi masukan atau saran melengkapi data. Pada akhirnya peserta didik akan memperoleh pengalaman dan pemahaman yang mendalam tentang materi yang dibelajarkan.

c. Memberdayakan sebagian peserta didik yang memiliki kompetensi di atas rata-rata termasuk ketua kelompok untuk menjadi tutor sebaya. Tugas mereka adalah membimbing temannya yang ada dalam kelompoknya agar berpartisipasi dalam memecahkan permasalahan, sehingga semua peserta didik memiliki pengetahuan dan pengalaman yang memadai dan bisa mencapai hasil belajar sesuai tujuan/kompetensi yang diharapkan. Hal ini dilakukan dengan tujuan agar tidak terjadi pembiaran pada peserta didik yang memiliki kompetensi rendah. 
Hasil analisis data observasi pada siklus II, pembelajaran IPA berbasis mind mapping sudah menunjukkan perkembangan yang signifikan. Pada siklus ini, guru sudah mengimplementasikan pembelajaran model discovery dengan baik. Setiap tahapan yang dilaksanakan disesuaikan dengan waktu dan kebutuhan peserta didik. Ditinjau dari segi waktu tahapan yang sangat membutuhkan waktu dan menentukan keberhasilan proses pembelajaran adalah data collection, data processing, dan verification. Apabila peserta didik mengalami kesalahan dalam mengumpulkan data atau informasi, maka akan keliru memproses data, dan membuat kesimpulan. Pada ketiga tahapan ini bila dilakukan dengan baik peserta didik tertantang mengembangkan kemampuan berpikir kritis, kreatif, dan kolaboratif. Sebelum peserta didik membuat kesimpulan materi, 3 tahap tersebut harus dilakukan dengan semaksimal mungkin untuk menghindari terjadinya miskonsepsi dan misunderstanding.

Dengan mengoptimalkan penerapan model discovery sebagian besar peserta didik sudah mampu mengidentifikasi masalah dan merumuskan hipotesis, menganalisis informasi, membuat kesimpulan, mengajukan dan menjawab pertanyaan, melibatkan diri dalam mengerjakan tugas kelompok, mengonstruksi pengetahuan yang diperoleh serta mengaitkannya dengan fenomena atau peristiwa yang sering diamati dan dialami dalam kehidupan sehari-hari. Dengan demikian keterampilan berpikir tingkat tinggi dari peserta didik mulai nampak dan harus dikembangkan secara berkelanjutan. Semakin sering peserta didik melakukan aktivitas-aktivitas tersebut, semakin mudah mereka mengatasi permasalahan kompleks serta bisa meraih prestasi belajar yang memuaskan. Hal ini sangat bersesuaian dengan penelitian yang dilakukan sebelumnya bahwa kemampuan peserta didik dalam berpikir kritis dan rasa ingin tahu dapat dikembangkan melalui beberapa kegiatan yakni mengamati, menanya, mengumpulkan data atau informasi melalui berbagai sumber belajar, mengasosiasi, dan mengomunikasikan. Kegiatan-kegiatan tersebut adalah pendekatan saintifik yang harus diterapkan dalam pembelajaran. 
Perubahan dan perkembangan yang terjadi pada siklus II bukan hanya disebabkan oleh aktivitas guru dalam menerapkan model pembelajaran discovery dengan baik. Namun, peran aktif dari sebagian peserta didik terutama ketua kelompok sebagai tutor, memberikan semangat, arahan, dan bimbingan kepada teman mereka yang memiliki kompetensi rendah (low competence) terutama kemampuan literasi. Dampaknya, peserta didik tersebut secara perlahan dapat mengembangkan kemampuannya walaupun membutuhkan waktu yang cukup dan berbagai strategi. Semua kelompok memperlihatkan antusiasnya dalam berkompetisi ingin meraih hasil yang terbaik. Peran tutor dalam memberikan motivasi kepada teman-temannya agar dapat berpartisipasi aktif, berkolaborasi dalam memecahkan permasalahan yang diberikan, memiliki rasa ingin tahu dengan seringnya mengajukan pertanyaan, mengkritik jawaban yang disampaikan, berani mengemukakan idenya dengan mengabaikan perasaan malu dan takut sangat perlu diberikan apresiasi. Guru sangat perlu memberikan umpan balik berupa penguatan (reinforcement) dan penghargaan terhadap keberhasilan peserta didik walaupun hanya berupa pujian untuk memelihara dan meningkatkan motivasi belajar mereka. Darmadi (2009) berpendapat bahwa pemberian penghargaan kepada peserta didik atas keberhasilan yang dicapainya dalam mengerjakan sesuatu merupakan salah satu cara dalam memotivasi, memacu semangat, mendorongnya untuk berbuat dan berprestasi lebih baik, serta peserta didik yang belum berprestasi akan termotivasi untuk bisa mengejar temannya yang sudah berprestasi.

Hasil penilaian kreativitas pada produk mind mapping untuk siklus II juga mengalami perkembangan. Terdapat 3 kelompok sudah bisa mengisinya dengan baik dan benar terutama penggunaan kata kunci, penulisan simbol/rumus kimia dan keterbacaan. Mereka bisa menemukan kata kunci/istilah dengan benar pada hubungan antarkonsep serta kesesuaian keterangan dengan subtopik. Amaliah (2015) melaksanakan penelitian di SMKN 1 Terpadu Kab. Luwu Provinsi 
Sulawesi Selatan dan menyimpulkan bahwa mind mapping dapat mengembangkan kreativitas, kemandirian belajar sehingga peserta didik dapat menguasai materi pembelajaran secara utuh/menyeluruh dan sistematis yang dibuktikan dengan meningkatnya hasil belajar.

Dari hasil wawancara yang dilakukan setelah proses pembelajaran pada pertemuan ke-3 siklus II, diketahui bahwa sebagian besar peserta didik menyatakan merasa tertarik dan senang dengan pembelajaran yang dilaksanakan. Mereka menyampaikan bahwa sebelumnya pernah mengikuti pembelajaran berbasis mind mapping akan tetapi kurang menarik, disebabkan hanya menggunakan media karton dan spidol warna. Setelah mengikuti pembelajaran berbasis mind mapping dengan media smartphone, keterampilan mereka dalam memanfaatkan media meningkat, membuat catatan atau rangkuman materi hanya dengan menggunakan kata kunci/istilah dan gambar dalam waktu yang singkat, mudah dipahami dan dimengerti, sehingga bisa memperoleh hasil belajar dengan kriteria tuntas pada penilaian harian. Bahkan, beberapa orang tua peserta didik merasa bangga dengan hasil pembelajaran mind mapping yang diperoleh anaknya. Orang tua tersebut memberikan penghargaan atau hadiah berupa media smartphone sistem android untuk memotivasi anaknya dalam mengikuti pembelajaran. Orang tua tersebut berharap agar barang yang dihadiahkan untuk anaknya dapat digunakan dengan sebaik-baiknya sebagai media pembelajaran dan komunikasi sekaligus sumber belajar.

Melalui proses pembelajaran guru dituntut dapat membimbing dan memfasilitasi peserta didik agar mereka bisa mengembangkan kompetensi yang dimilikinya, membantu dapat mengenal dan memahami kekuatan atau kemampuan mereka, untuk selanjutnya memberikan motivasi agar bisa belajar sebaik mungkin sehingga dapat mewujudkan keberhasilan berdasarkan kemampuan yang dimiliki. Di samping itu, guru sangat perlu mengenal lebih dekat bakat, minat, motivasi, harapanharapan serta beberapa dimensi khusus kepribadian mereka. 
Secara umum pembelajaran berbasis mind mapping dapat membantu peserta didik memahami materi sebagai suatu pengetahuan yang utuh sehingga dapat diingat dengan mudah dan cepat serta efisien. Mind mapping dikembangkan berdasarkan sebuah kenyataan bahwa kemampuan otak manusia bisa menampung ribuan imajinasi, jutaan kreasi, dan miliaran visualisasi. Otak dapat diumpamakan sebagai hutan raya tempat tumbuhnya ribuan pohon, jutaan cabang, dan miliaran ranting yang memiliki keterkaitan yang sangat erat. Dari perumpamaan tersebut muncul metode/teknik mind mapping dan diterapkan dalam pembelajaran.

Pembelajaran berbasis mind mapping sangat baik diimplementasikan dalam pembelajaran IPA terutama pada materi yang bersifat abstrak dan kompleks. Pembelajaran tersebut akan memudahkan peserta didik untuk memahami dan mengingat materi secara utuh, dan merangsang kemampuan membandingkan pengetahuan dan pengalaman yang ada baik berupa fakta, konsep, maupun simbol. Beberapa manfaat mind mapping sesuai pendapat Deporter \& Hernacki (2011) adalah dapat memusatkan pikiran, bersifat fleksibel, meningkatkan pemahaman dan menyenangkan, membantu peserta didik dapat membuat rangkuman yang sangat menarik dalam waktu yang singkat, membuka pemahaman yang lebih baik, lebih aktif, kritis, kreatif, inovatif dan mandiri serta merangsang munculnya ide-ide baru sehingga materi pembelajaran lebih cepat dan mudah dipahami secara keseluruhan.

Pembelajaran IPA merupakan pengetahuan yang terdiri dari proses yang dapat menghasilkan produk berupa prinsip, fakta, konsep, dan prosedur. Dalam melakukan proses tersebut peserta didik diharapkan selalu dilatih untuk bisa berpikir ke tingkat lebih tinggi sampai metakognitif, dapat membentuk sikap ilmiah dalam melakukan penyelidikan semua komponen baik biotik maupun abiotik, mencari hubungan sebab dan akibat yang dapat memunculkan permasalahan baru dan dapat diselesaikan dengan metode ilmiah. Dalam mengikuti pembelajaran IPA berbasis mind mapping dengan media smartphone 
peserta didik tidak hanya memperoleh keterampilan dan pengetahuan, tetapi juga menemukan sendiri kompetensi tersebut. Apabila hal ini dikembangkan secara berkesinambungan, akan terbentuk konsep diri anak yang ditandai dengan terbentuknya mental sehat, sifat terbuka, rasa aman, kritis, kreatif, dan karakter lain yang mendukung terbentuknya manusia yang berkualitas.

Beberapa faktor yang dapat memengaruhi pengembangan kemampuan berpikir kritis dan kreatif antara lain lingkungan, motivasi, sarana, dan peluang. Bukan hanya peserta didik yang dituntut memiliki kemampuan tersebut, seorang guru pun harus memilikinya terlebih dahulu sebelum mengembangkannya pada peserta didik. Dengan berpikir kritis dan kreatif seseorang dapat mengubah, mengatur, menyesuaikan atau memperbaiki pikirannya sehingga bisa bertindak dengan tepat dalam mengambil keputusan. Guru yang tidak memiliki kemampuan berpikir kritis dan kreatif maka dapat diprediksi peserta didiknya pun belum tentu memiliki kemampuan tersebut. Guru selain bisa menguasai materi, harus kritis dan kreatif dalam menyikapi permasalahan yang dihadapi dalam pembelajaran.

Berbagai upaya yang perlu dilakukan untuk mengembangkan kemampuan berpikir kritis dan kreatif guru dan peserta didik adalah (1) memahami latar belakang pribadi masing-masing, (2) menciptakan situasi dan kondisi untuk mendorong timbulnya pemikiran kritis dan kreatif, (3) mencari kesempatan atau peluang untuk menerapkan hasil pemikiran kritis dan kreatif dalam suasana yang terkendali dan terkontrol,dan 4) mengembangkan kemampuan berimajinasi dengan mengidentifikasi dan menemukan permasalahan baru yang bisa meningkatkan inteligensia.

Kemampuan berpikir kritis dan kreatif yang dimiliki seseorang harus disertai dengan kemampuan dalam berkolaborasi dan berkomunikasi secara global untuk menjadi dasar dan bekal dalam menghadapi tantangan abad ke-21. Kemampuan berkolaborasi sangat dibutuhkan sebelum membuat kesimpulan atau mengambil suatu 
keputusan. Raupu (2020) menyimpulkan hasil penelitiannya bahwa kolaborasi peserta didik akan terjadi apabila diberikan stimulus seperti media pembelajaran. Kemampuan tersebut menekankan pada berbagi informasi dan pengetahuan dalam kegiatan diskusi kelompok secara aktif, saling membantu dan berkontribusi dalam memecahkan permasalahan untuk mencapai tujuan bersama. Suatu prestasi yang diraih tidaklah semata-mata ditentukan oleh kemampuan seseorang secara utuh, melainkan keberhasilan semakin baik apabila diperoleh dengan cara berkolaborasi dalam kelompok dengan cara yang terstruktur dengan baik.

Hasil pemikiran yang timbul dari dua atau tiga otak akan lebih baik dari pada pemikiran satu otak dalam pengambilan suatu keputusan. Kemampuan berkomunikasi merupakan hal yang penting dalam menyampaikan pendapat atau pengalaman sebagai laporan pemecahan masalah berdasarkan hasil pemikiran kreatif dan data yang akurat, dapat dipertanggungjawabkan baik secara lisan, menggunakan format atau melalui media teknologi. Laporan yang dikomunikasikan meliputi tahap persiapan, proses pelaksanaan, hasil, dan kesimpulan. Komunikasi dapat membantu meningkatkan hubungan baik dengan orang lain terutama keluarga dan sahabat. Kemampuan berkomunikasi dapat memupuk karakter seseorang seperti teliti, jujur, tanggung jawab, toleransi; mengembangkan kemampuan berpikir kritis dan kreatif secara sistematis, memamerkan hasil karya, mengungkapkan pendapat secara jelas dan singkat; serta membiasakan cara menyampaikan ide dengan sopan dan bahasa yang santun. Hal tersebut bersesuaian dengan hasil penelitian Hidayati (2020) yang menyimpulkan bahwa pemanfaatan media pembelajaran yang cocok dapat mengubah perilaku peserta didik yang mencakup aspek komunikasi, kolaborasi, berpikir kritis, dan kreatif serta membentuk karakter jujur, disiplin, dan kerja sama.

Guru sebagai fasilitator, mediator, dan motivator sekaligus pengembang media pembelajaran dituntut harus mampu menganalisis karakteristik dari setiap strategi atau pendekatan yang diterapkan dalam 
pembelajaran, kreatif dalam memilih dan menetapkan strategi atau pendekatan yang digunakan dalam penyajian setiap materi. Strategi maupun pendekatan yang dipilih sebaiknya disesuaikan dengan minat dan taraf perkembangan peserta didik, bisa memotivasi, menginspirasi, memfasilitasi efektifnya pelaksanaan proses pembelajaran, menciptakan suasana belajar yang kondusif dan bermakna, mendorong terjadinya interaksi, melayani perbedaan individu, memediasi pembelajaran yang bersifat kontekstual sehingga dapat mencapai hasil sesuai harapan. Hasil belajar akan semakin baik bilamana intensitas keaktifan jasmani, emosional, dan intelektual peserta didik semakin tinggi. Hal ini ditandai dengan keterlibatan mereka secara optimal dalam proses pembelajaran. Pembelajaran berbasis aktivitas seperti ini tergolong pembelajaran HOTS yang sangat diharapkan untuk dilaksanakan oleh semua guru mata pelajaran.

Diperlukan keseriusan dari semua pihak dalam menerapkannya, terutama ketegasan dan pendampingan dari kepala sekolah kepada semua guru mata pelajaran, fungsi penguatan dan kontrol dari pengawas perlu dimaksimalkan. Semakin sering guru menerapkan pembelajaran berbasis aktivitas (menalar, menganalisis, mengevaluasi, dan mengkreasi), kemampuan peserta didik dalam berpikir kritis dan kreatif semakin berkembang sehingga peserta didik tersebut akan mudah menyelesaikan soal-soal yang bersifat HOTS. Dalam menyelesaikan soal HOTS peserta didik sangat membutuhkan keterampilan berpikir logis dan sistematis, keterampilan bernalar, memilah dan mengolah informasi.

\section{Penutup}

Berdasarkan hasil observasi dan analisis data dapat dibuat simpulan bahwa, pembelajaran IPA berbasis mind mapping adalah pembelajaran yang menggunakan pemetaan hasil pemikiran dengan teknik penyaluran ide atau gagasan dalam satu materi melalui pemakaian kata kunci, istilah, gambar, dan simbol yang merupakan ringkasan suatu materi secara utuh dan lengkap. Pembelajaran ini memudahkan peserta didik 
dalam berpikir ke beberapa arah, mengubah cara belajar dari selalu diberi tahu menjadi aktif mencari tahu, dapat memahami materi secara utuh sehingga kualitas pembelajaran menjadi lebih baik. Pembelajaran IPA berbasis mind mapping dapat mengembangkan kemampuan berpikir kritis dan kreatif masing-masing sebesar 35\%, komunikatif 40\%, dan kolaboratif 35\%.

Agar pembelajaran tidak membosankan dan diminati semua peserta didik serta berubah menjadi pembelajaran yang menarik, menyenangkan, dan bermakna, guru perlu merancang dan menerapkan sistem pembelajaran secara sistemik dan sistematik. Dengan demikian dapat mengembangkan kemampuan peserta didik bisa berpikir kritis, kreatif, komunikatif, dan kolaboratif sesuai harapan pemerintah pada generasi abad ke-21.

Penelitian ini dapat dikembangkan oleh guru lainnya agar dalam melaksanakan kegiatan pembelajaran tidak terfokus pada pencapaian target kurikulum. Sebaliknya, guru dapat melakukan inovasi dan kreasi, dapat mengembangkan sistem pembelajaran melalui berbagai strategi, pendekatan, metode/model, serta menciptakan dan memanfaatkan media pembelajaran yang membelajarkan peserta didik. Tujuannya agar dapat menghasilkan out put yang berkarakter dan berkualitas.

\section{Ucapan Terima Kasih}

Terselesaikannyaartikel hasil penelitian ini berkat dukungan dan kerja sama dari beberapa pihak. Oleh karena itu, peneliti menyampaikan terima kasih yang tak terhingga kepada Rostin Abas, S, Pd. M.M. sebagai kepala SMP Negeri Widyakrama Kabupaten Gorontalo, pengurus dan anggota MGMP IPA Newton, dan Fatmahwaty Datau, M.Pd. yang selalu memberikan motivasi, petunjuk, dan arahan kepada peneliti dalam mengembangkan profesi sebagai pendidik, memberikan sumbangan pemikiran dan saran pada pelaksanaan diseminasi. Semoga semua pihak yang sudah berpartisipasi dalam penelitian ini memperoleh imbalan pahala dari Allah SWT. 


\section{Daftar Referensi}

Amaliah, Nur. (2015). Penggunaan Software E-Draw Mind Map dengan Model Mind Mapping (Peta Pikiran) dalam Mengembangkan Kreativitas Berpikir Peserta Didik pada Mata Pelajaran Biologi. Karya Inovasi, Simposium Guru dan Tenaga Kependidikan Nasional, pdf.

Darmadi, H. (2009). Kemampuan Dasar Mengajar, Landasan Konsep dan Implementasi. Bandung: Alfabeta

Deporter, B., \& Mike, H. (2011). Quantum Learning. Bandung: Kaifa

Devy, P. K. (2016). Modul Guru Pembelajar Mata Pelajaran IPA SMP Kelompok Kompetensi C. Jakarta: Direktorat GTK Kemdikbud.

Hidayati, M. (2020). Media History Fun Thinkers Untuk Meningkatkan Keterampilan 4C dan Hasil Belajar IPS. Jakarta. Jurnal Didaktika Pendidikan Dasar 4 (2), 581-600.

Kementerian Pendidikan dan Kebudayaan. 2019. Program Pengembangan Keprofesian Berkelanjutan (PKB) Melalui Peningkatan Kompetensi Pembelajaran (PKP) Berbasis Zonasi. Penilaian Berorientasi Higher Order Thinking Skills (HOTS). Jakarta: Direktorat GTK Kemdikbud.

Raupu, M. S. (2019). Efektivitas Model Pembelajaran Group Investigation Berbantuan Media DUIT Terhadap Peningkatan Keterampilan Kolaborasi Peserta Didik. Jakarta. Jurnal Didaktika Pendidikan Dasar, 3 (2), 591-606.

Purwanto, M. N. (2010). Prinsip-prinsip dan Teknik Evaluasi Pendidikan. Bandung: Remaja Rosdakarya.

Slameto. (2010). Belajar dan Faktor-faktor yang Mempengaruhinya. Jakarta: Rineka Cipta. 